European Journal of Sustainable Development Research

2019, 3(1), em0065

ISSN: 2542-4742

\title{
Uptake Hazardous Dye from Wastewater Using Water Hyacinth as Bio- Adsorbent
}

\author{
Shahanaz Parvin ${ }^{1}$, Afzal Hossen ${ }^{1}$, Wasikur Rahman 1*, Israfil Hossen ${ }^{1}$, Abdul Halim 1, \\ Biplob Kumar Biswas ${ }^{1}$, Abu Shamim Khan ${ }^{2}$
}

1 Jessore University of Science and Technology, Department of Chemical Engineering, 7408 Jessore, BANGLADESH

${ }_{2}^{2}$ Asia Arsenic Network, Arsenic Center, Jessore, BANGLADESH

*Corresponding Author: mwrahman.ump@gmail.com

Citation: Parvin, S., Hossen, A., Rahman, W., Hossen, I., Halim, A., Biswas, B. K. and Khan, A. S. (2019). Uptake Hazardous Dye from Wastewater Using Water Hyacinth as Bio-Adsorbent. European Journal of Sustainable Development Research, 3(1), em0065. https://doi.org/10.20897/ejosdr/3917

Published: February 6, 2019

\begin{abstract}
The existing study demonstrates that water hyacinth (eichhorniacrassipes) is a potential adsorbent for the removal of Congo red dye from synthetic wastewater by batch process. The experiments were conducted to study the influence of various parameters such as initial dye concentration, $\mathrm{pH}$, contact time and adsorbent dosage at different operating conditions. The effect of $\mathrm{pH}$ and dye concentration was found to be significant and the maximum removal was detected at pH 5 and concentration $100 \mathrm{ppm}$; considered to be optimum values. The removal of Congo red was consistent initially proportional to the adsorbent dosage. The adsorption process followed Langmuir adsorption isotherm model; point out that the process supported monolayer adsorption of Congo red on the adsorbent surface. Adsorption kinetics closely followed the pseudo-second-order model and mass transfer analysis indicated better transportation of adsorbate from solution phase to solid phase. These results point out suitability of the locally available low cost adsorbents in the niche area of wastewater treatment and can be implemented in commercial dye enriched industrial effluent.
\end{abstract}

Keywords: adsorption, water hyacinth, Congo red, kinetic study, isotherm, mass transfer

\section{INTRODUCTION}

Water resources, soil fertility, aquatic organisms and ecosystem integrity are adversely affected by toxic effluents which are discharged from various chemical industries. Textile industry is one of the chemical industries where coloring effluents are the major encountered problems. The textile wastewater is rated as the most polluting discharges among all industrial sectors (Awomeso et al., 2010, Vilaseca et al., 2010). The textile industry produces large amount of dye contained wastewater in dyeing and finishing processes. Dyes usually have complex aromatic molecular structure which makes them non-biodegradable (Gharbani et al., 2008, Taha, 2011). Due to nonbiodegradability, the components of dye substances create severe problem not only to the ecosystem but also create toxicity to the biological life (Choi et al., 2004). Various physical and chemical treatment processes such as coagulation, flocculation, membrane filtration, etc. are commercially practiced and removal efficiency of these processes are satisfactory (Robinson et al., 2001), however, these processes are costly, large amount of sludge is produced during operation and ecologically unsafe. From these perspectives, adsorption is one of the most effective and alternative methods to remove dyes from wastewater (Deans et al., 1992, Nigam et al., 2000). Adsorption is the method for separation of mixtures on laboratory and industrial scale where it is a surface 
phenomenon that can be defined as the increase in concentration of a particular component at the interface between two phases. In this study, we represent how dye can be removed from synthetic wastewater through adsorption by using water hyacinth as bio-adsorbent. Water hyacinth is one of the abundant weed in the world but it can be employed as a bio-adsorbent after some modification that is capable to remove various industrial dyes such as methylene blue, Congo red, crystal violet, malachite green from aqueous solution (Nath et al., 2013). In case of heavy metal removal from aqueous solution, water hyacinth showed great potentiality. Water hyacinth has the ability to uptake copper, cadmium, chromium, and zinc from textile wastewater with high efficiency (Mokhtar et al., 2011, Ajayi and Ogunbayo, 2012; Mahmood et al., 2005). Nowadays, a large number of low cost adsorbents have drawn attention to the researchers due to their capacity, availability and ease to operation.These are, for example, rice husk (Reddy et al., 2013), wood dust (Garg et al., 2004), tree bark powder (paul 2013), peat (Fernandes et al., 2006), lignin (Cotoruelo et al., 2010), wheat bran (Ata et al., 2012), brown sea weed (Vijayaraghavan et al., 2008), banana and orange peel (Annadurai et al., 2002), fly ash (Janos et al., 2003), pineapple stem waste (Hameed et al., 2009), tuberous pulp, sugarcane pulp, coconut pulp (Pramanik et al., 2011), etc. However, the search for simple, economic, eco-friendly and highly effective adsorbents are still challenging. From these perspectives, water hyacinth was selected as a bio-adsorbent to remove dye from synthetic wastewater.

In the present work, naturally available low-cost adsorbent, such as water hyacinth has been used as an adsorbent for Congo-red dye removal from aqueous solution. The consequence of the experimental parameters such as initial $\mathrm{pH}$, concentration of dye, adsorbent dosage and contact time has been investigated. The outcome of the experiments was analyzed by Langmuir adsorption isotherm, mass transfer and kinetics viewpoints.

\section{MATERIALS AND METHODS}

\section{Materials}

Water hyacinth was collected from the local area of Jessore University of Science and Technology, Bangladesh. The chemical substances, e.g., Congo red (CR) dye, $\mathrm{HCl}$ and $\mathrm{NaOH}$ were purchased from Merck, Germany. Stock solution of Congo red was prepared by dissolving $696.665 \mathrm{~g} / \mathrm{mol}$ of dye in doubled distilled water and different concentrations $(25,50,100,200,300,400$ and $500 \mathrm{ppm})$ of solution were made by dilution of the stock solution.

\section{Preparation of Adsorbent}

Water hyacinth was carefully washed by distilled water to remove the dirt and mud. It was then sun dried and acid washed to eliminate the soluble impurities. Then acid washed sample was dried again in an oven at $105^{\circ} \mathrm{C}$ for $2 \mathrm{hrs}$ to leave out the moisture from it. The dried adsorbent was crushed in a micro-plant grinding machine and converted into fine powder which was stored in air tight plastic containers for further use in the whole experiment.

\section{Adsorbent Characterization and Analysis}

UV-1650 spectrophotometer (Shimadzu Co., Japan) was used to measure the concentration of solution where maximum absorbance wavelength was $450 \mathrm{~nm}$. $\mathrm{pH}$ of the solutions were studied over the range from 4 to 8 through $\mathrm{pH}$ meter.

\section{Adsorption Experiments}

The batch experiments were run out to investigate the influence of various parameters including contact time (0 to 210 mins), $\mathrm{pH}$ (4 to 8 ), adsorbent dosages $(0.5$ to $5 \mathrm{~g} / \mathrm{L}$ ). In this study $250 \mathrm{ml}$ conical flasks were used to keep $100 \mathrm{ml}$ adsorbate solution of various concentrations (25,50,100, 200,300, 400 and $500 \mathrm{ppm}$ ) and known amount of adsorbent were added into each flask at different conditions which shaken continuously at a constant oscillation of $211 \mathrm{osc} / \mathrm{min}$ for $3.5 \mathrm{hrs}$. Then the solution was filtered and the remaining sample was analyzed to determine the adsorption percentage of Congo red which computed by the following equation (1):

$$
\% \text { Removal of } \mathrm{CR}=\frac{C_{0}-C_{t}}{C_{0}} \times 100 \%
$$

where, $C_{0}$ is the initial concentration $(\mathrm{mg} / \mathrm{L})$ and $C_{t}$ is the concentration at time $t$. The amount of $\mathrm{CR}$ adsorbed per unit mass of the adsorbent, $q_{\boldsymbol{e}}(\mathrm{mg} / \mathrm{g})$ was evaluated by the following mass balance equation (2):

$$
q_{e}=\frac{\left(C_{0}-C_{e}\right) V}{m}
$$

where, $C_{0}$ and $C_{e}$ are the concentrations $(\mathrm{mg} / \mathrm{L})$ of Congo-red at initial and at equilibrium, correspondingly. $V$ is the volume $(\mathrm{L})$ of the solution and $m$ is the mass of the adsorbent $(\mathrm{g})$. 


\section{Pseudosecondorder Model}

Adsorption capacity of dye on the adsorbent particles was assumed proportional to the active sites of the surface. For pseudo-second order kinetic rate, the above equation is as in the following equation (3):

$$
\frac{t}{q_{1}}=\frac{1}{k_{2} q_{e}^{2}}+\frac{1}{q_{e}} t
$$

If second-order kinetic is applied, the plot of $t / q_{1}$ against $t$ of the above equation should demonstrate a linear relationship and $q_{e}$ and $k_{2}$ can be determined from the slope and intercept.

\section{Intra-particle Diffusion Study}

Diffusion coefficient $\left(K_{i p}\right)$ for the intra-particle transport of $\mathrm{CR}$ has been calculated at initial dye concentrations and $\mathrm{pH}$ by employing the rate equation (4) expressed by Vadivalen and Kumar, 2005:

$$
q_{t}=\varnothing+K_{i p} \sqrt{t}
$$

\section{Langmuir Adsorption Isotherm}

Langmuir represents the equilibrium distribution of dye molecules between the solid and liquid phases. Langmuir isotherm is valid for monolayer adsorption onto a surface containing a finite number of identical sites.

Based upon these assumptions, Langmuir represented the following equation (5):

$$
q_{e}=\frac{Q_{o} K_{L} C_{e}}{1+K_{L} C_{e}}
$$

Langmuir adsorption parameters were determined by transforming the Langmuir equation into linear form (6):

$$
\frac{1}{q_{e}}=\frac{1}{Q_{0}}+\frac{1}{Q_{0} K_{L} C_{e}}
$$

where, $C_{e}$ is the equilibrium concentration of adsorbate $(\mathrm{mg} / \mathrm{L}), q_{e}$ is the amount of dye adsorbed per gram of the adsorbent at equilibrium $(\mathrm{mg} / \mathrm{g}), Q_{0}$ is the maximum monolayer coverage capacity $(\mathrm{mg} / \mathrm{g})$ and $K_{L}$ is the Langmuir isotherm constant $(\mathrm{L} / \mathrm{mg})$.

\section{Mass Transfer Analysis}

Mass transfer analysis for adsorption of Congo red on the water hyacinth was carried out using the Mckay et al. (1981) equation (7):

$$
\ln \left(\frac{C_{t}}{C_{o}}-\frac{1}{1+M K_{b q}}\right)=\ln \left(\frac{M K_{b q}}{1+M K_{b q}}\right)-\left(\frac{1+M K_{b q}}{M K_{b q}}\right) \beta S_{s} t
$$

where, $M$ is the mass of the adsorbent per unit volume $(\mathrm{g} / \mathrm{L}), K_{b q}$ is the constant obtained by multiplying $Q_{o}$ and $K_{L}$ which are defined in 2.7 section, $S_{S}$ is the external surface area of the adsorbent per unit volume $\left(\mathrm{m}^{-1}\right), \beta$ is the mass transfer coefficient ( $\mathrm{cm} / \mathrm{min}$ )and $t$ is the contact time ( $\mathrm{min}$ ).

The plot of $\ln \left\{C_{t} / C_{0}-1 /\left(1+M K_{b q}\right)\right\}$ versus $t$ is carried out. The values of mass transfer coefficient, $\beta$ were determined graphically from the slope $\left\{\left(1+M K_{b q}\right) / M K_{b q}\right\} \beta S_{s}$ of the individual plots.

\section{RESULTS AND DISCUSSION}

\section{Removal Properties of CR}

\section{Effect of $p H$}

The removal of Congo red dye from synthetic waste water with varying $\mathrm{pH}$ is illustrated in Figure 1 where initial dye concentration $100 \mathrm{ppm}$ and contact time $150 \mathrm{~min}$.

From the figure, it can be seen that the maximum dye adsorption (87\%) was obtained at $\mathrm{pH} 5$ and gradual decrease in adsorption take place with increasing the value of $\mathrm{pH}$. Only $58 \%$ dye adsorption take place at $\mathrm{pH} 8$. This is due to the fact that, Congo red is anionic dye and at higher $\mathrm{pH}, \mathrm{OH}^{-}$ions are plenty and it can compete with the anionic dye which accounts low adsorption. At lower $\mathrm{pH}$, due to the electrostatic attraction between negative charged dye molecules and positive charged adsorbent surface higher adsorption can be observed (AboulFetouh et al., 2010; Alam et al., 2014).For these reason, pH 5 was taken as optimum result for further whole experiment herein. 


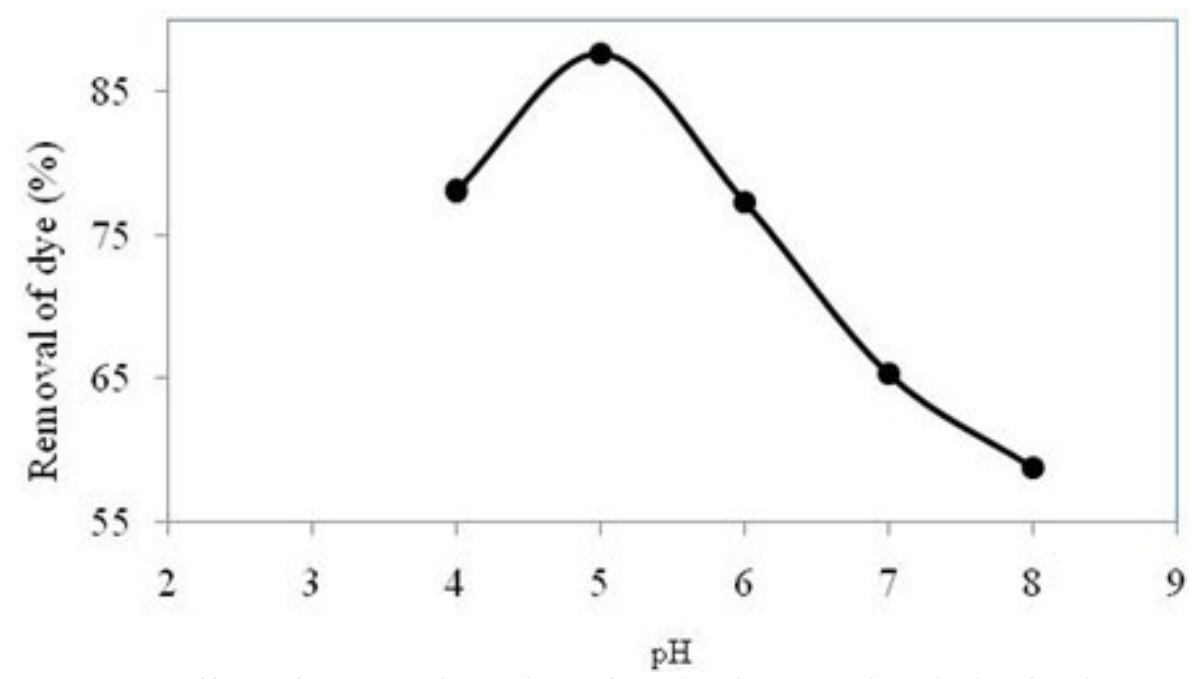

Figure 1. Effect of $\mathrm{pH}$ on adsorption of $\mathrm{CR}$ by the water hyacinth adsorbent at optimum concentration $100 \mathrm{ppm}$, adsorbent dosage $1.0 \mathrm{~g} / \mathrm{L}$ and contact time $150 \mathrm{~min}$

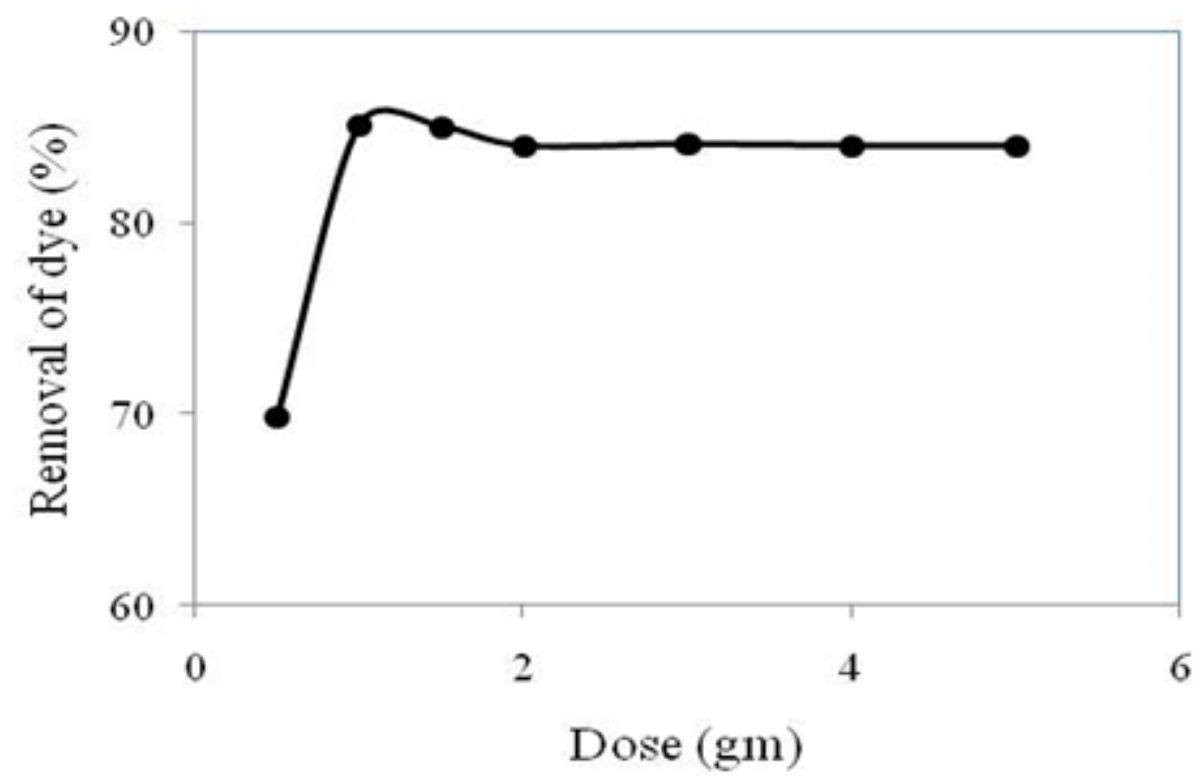

Figure 2. Effect of adsorbent dosage on \% of dye removal by the adsorbent at optimum concentration $100 \mathrm{ppm}$, pH 5 and contact time $150 \mathrm{~min}$

\section{Effect of Adsorbent Dosage}

The result of Congo red dye removal where initial concentration $100 \mathrm{ppm}$, contact time $150 \mathrm{~min}$ and optimum $\mathrm{pH} 5$ with varying amount of adsorbent dosages is depicted in Figure 2.

From the Figure, it can be seen that adsorption of dye increased from $69 \%$ to $85 \%$ with increasing adsorbent dose from 0.5 to $1.0 \mathrm{~g} / \mathrm{L}$. After that when we increased the adsorbent dose, the dye removal\% decreased due to the fact that there might be formation of particle aggregation resulting in a decrease in the total surface area which responsible for decreasing adsorbed amount per unit mass (Khan et al., 2015). Even if the uptake of dye increased by increasing the adsorbent dose beyond a dose of $1.0 \mathrm{~g} / \mathrm{L}$, the rise of dye removal $\%$ is insignificant and capacity of adsorbent is low. Therefore, further increase of dose result the much production of sludge and wastage of material. Similar result was found from lead ion removal by bamboo based activated carbon which is reported in Khan et al., 2015. Thus $1.0 \mathrm{~g} / \mathrm{L}$ of adsorbent dose was taken as an optimum dose for further experiments.

\section{Effect of Dye Concentration}

This study was performed by changing the initial dye concentration in the range of 25 to $500 \mathrm{ppm}$ (Figure 3) with optimum conditions received from previous experiments (adsorbent dose $1.0 \mathrm{~g} / \mathrm{L}$, contact time $150 \mathrm{~min}$ and $\mathrm{pH}$ 5). 


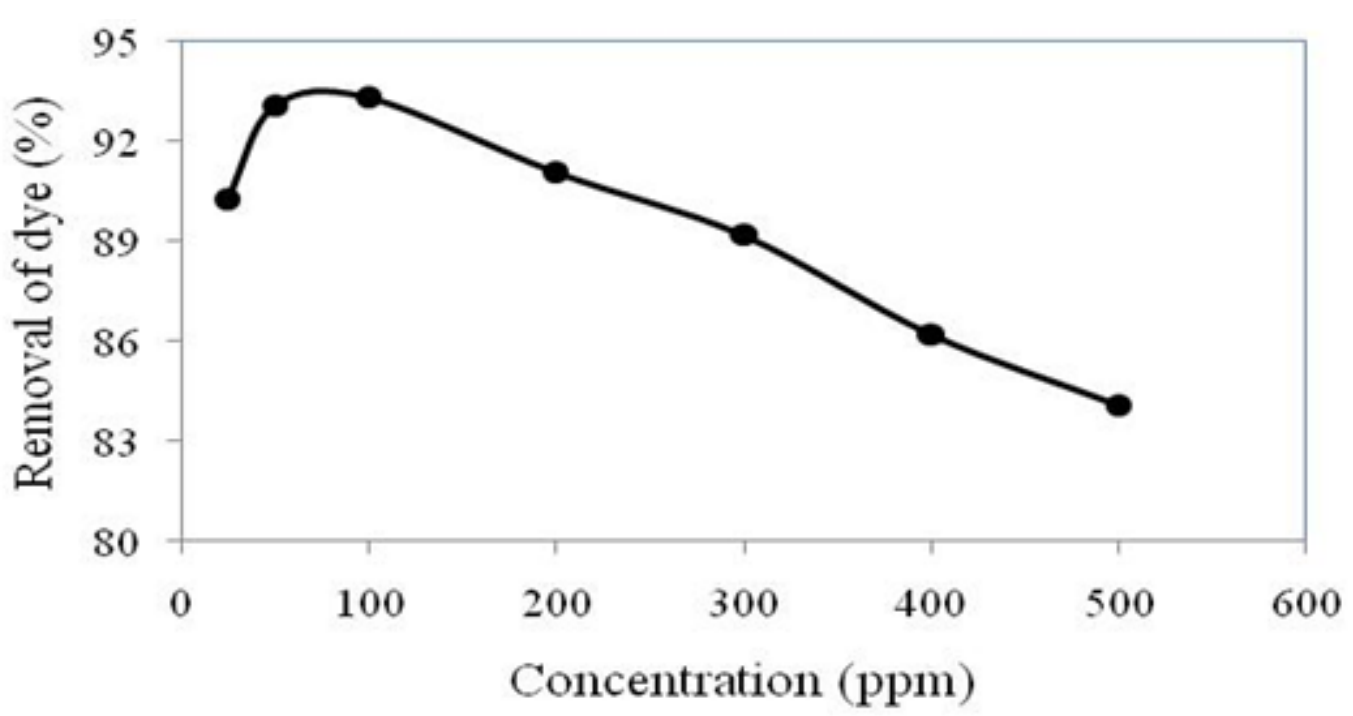

Figure 3. Effect of dye concentration on the adsorbent at optimum adsorbent dosage of $1.0 \mathrm{gm} / \mathrm{L}$, pH 5 and contact time $150 \mathrm{~min}$

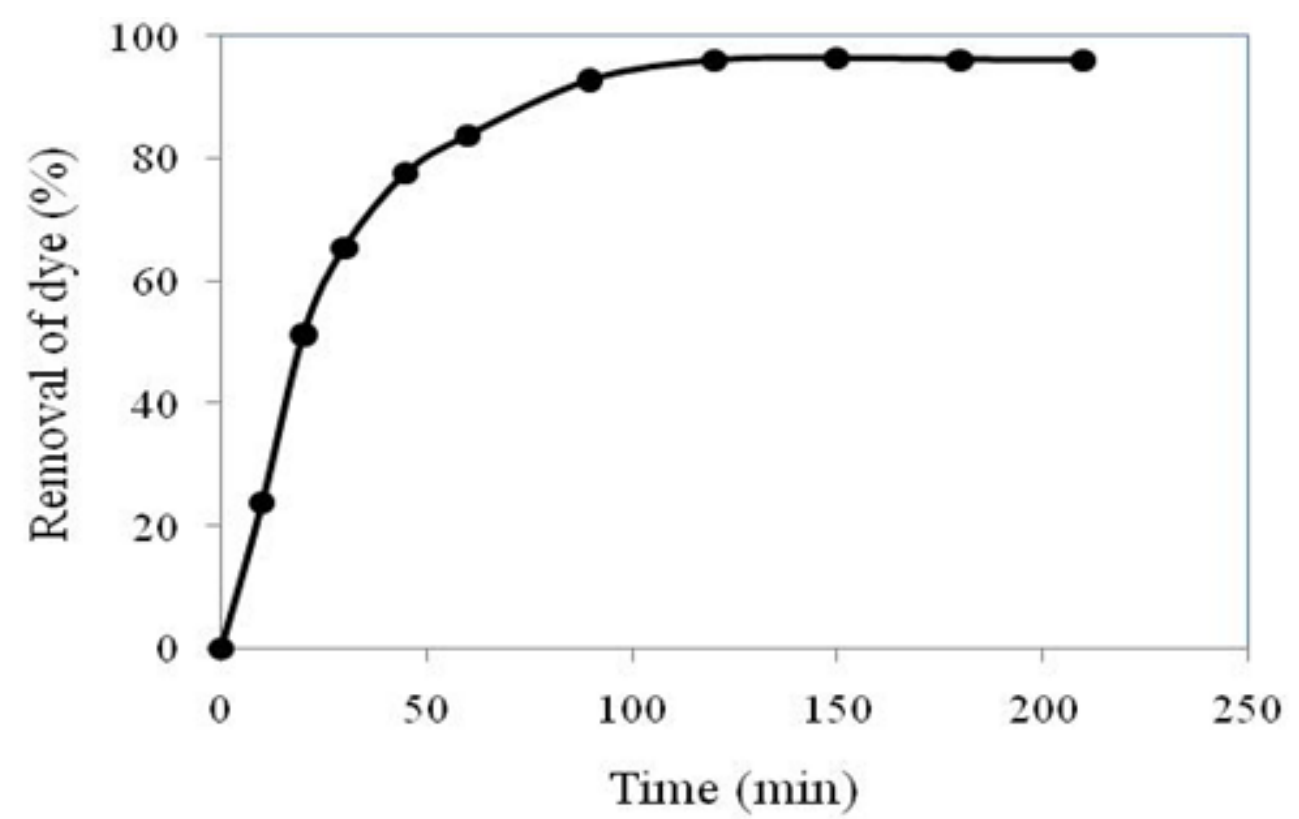

Figure 4. Effect of contact time of the CR dye on the adsorbent at optimum concentration $100 \mathrm{ppm}$, adsorbent dosage of $1.0 \mathrm{gm} / \mathrm{L}$ and $\mathrm{pH} 5$

The initial dye concentration provided significant driving force to overcome all mass transfer resistances of the dye between the aqueous and solid phases (Ho et al., 2005). In this study, when the initial concentration of dye increased from 25 to $100 \mathrm{ppm}$, the percentage of dye removal using water hyacinth increased from 90 to $93 \%$ and after that the removal percentages fall with increasing dye concentration. The reasons behind that, the increase of adsorption capacity might be due to the increment of driving force that is concentration gradient which causes an increased number of dye particles coming in contact with the adsorbent. On the other hand, number of available adsorption sites in adsorbent is the same for all concentrations. Thus concentration increases with the more number of dye particles but adsorbent dose remain same, therefore, dye competes with the same adsorption sites. As a result, some dye particles without being adsorbed retain in the system and decrease the removal percentage upon increases the Congo red dye concentration.

\section{Effect of Contact Time}

Effect of contact time on the removal of dye by the water hyacinth as adsorbent is illustrated in Figure 4. It showed that the removal percentage increased (0 to $96 \%)$ with the increase in contact time (0 to 150 min). Highest removal $(96 \%)$ was obtained at and above $150 \mathrm{~min}$. It means that the removal rate becomes slower with time and finally a saturation stage is obtained. Similar result was discussed in Kumar and Bilal, 2018. 


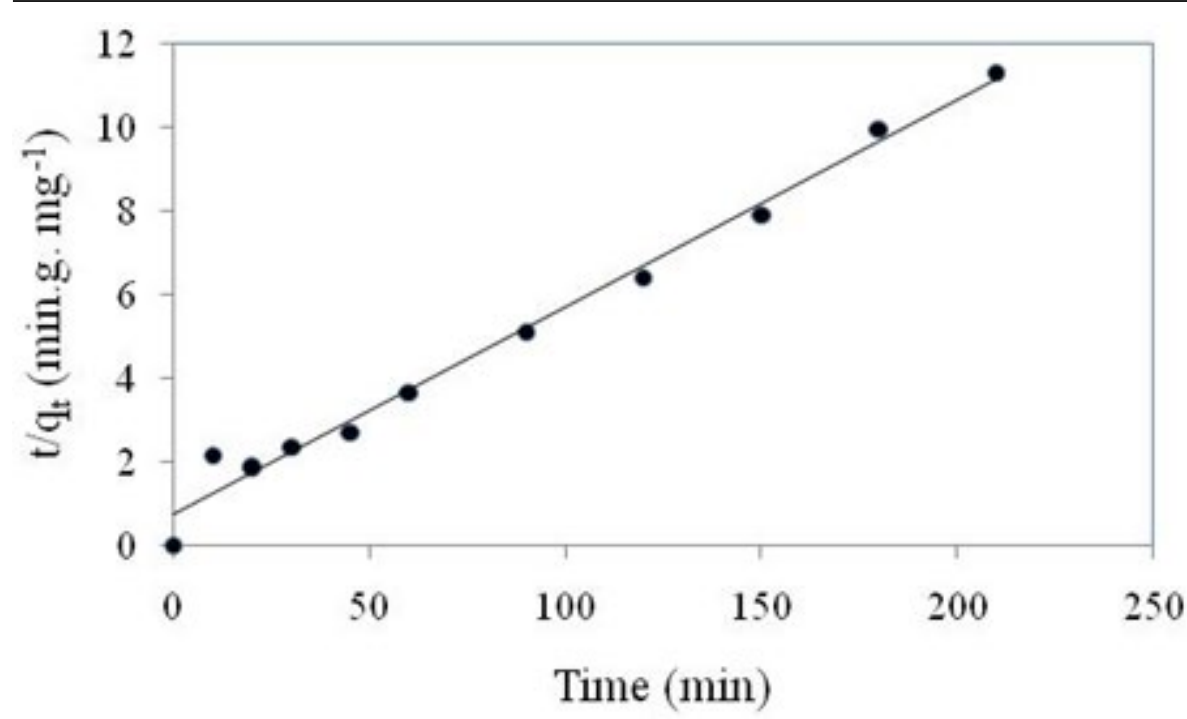

Figure 5. Pseudo second order kinetic model for the removal of $\mathrm{CR}$ using water hyacinth at optimum concentration $100 \mathrm{ppm}$, adsorbent dosage $1.0 \mathrm{~g} / \mathrm{L}$ and $\mathrm{pH} 5$

Table 1. Kinetics results for adsorption of CR onto water hyacinth

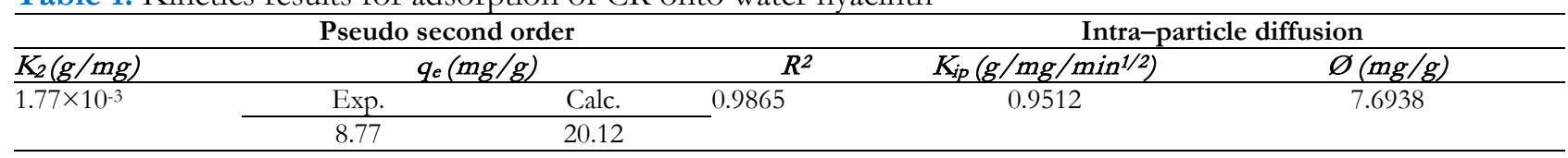

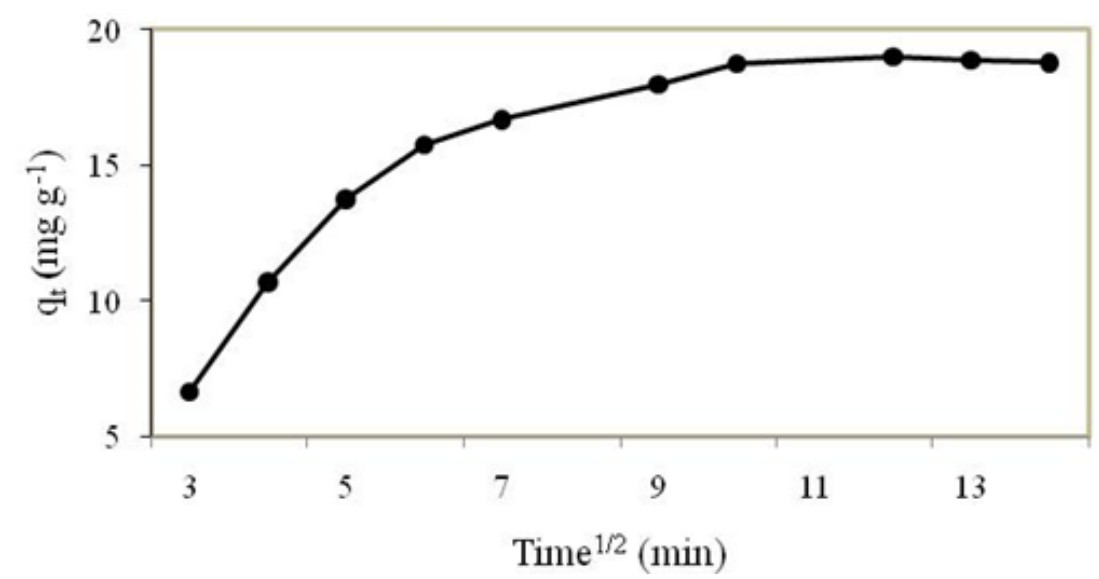

Figure 6. Intra-particle diffusion model for the removal of CR onto water hyacinth

\section{Adsorption kinetics}

Pseudo second order kinetic model was studied at optimized operating conditions such as concentration 100 ppm, pH 5 and the results were described in Figure 5. The figure $\left(t / q_{t}\right.$ versus $\left.t\right)$ showed linear plot from which the value of $q_{e}$ and $k_{2}$ were calculated (Table 1). The result revealed that $R^{2}$ value is close to 1 and linearity of this curve indicates that the kinetic data fitted well with the pseudo second order model. Similar results were also reported in Cheng et al., 2015 to uptake CR dye via activated carbon.

For the intra-particle diffusion analysis, if the plot of $q_{t}$ versus $t^{1 / 2}$ gives a straight line that pass through the origin which indicates the intra-particle diffusion model contributes in the rate determining step (Ghorai and Pant 2005) but in Figure 6, this linear relationship does not pass through the origin that imply the intra-particle diffusion model was not rate controlling step.

\section{Adsorption Isotherm Study}

In the present study, the plot of $1 / q_{e}$ against $1 / C_{e}$ gives straight line shown in Figure 7 with a slope of $1 / Q_{0} K_{L}$ and intercept of $1 / Q_{0}$. From the plot we can notice that the value of regression correlation co-efficient $\left(R^{2}\right)$ is 0.9899 which is very close to 1 and indicates that the obtained data are well fitted in Langmuir isotherm model and also suggests that monolayer sorption exists under the experimental conditions. 


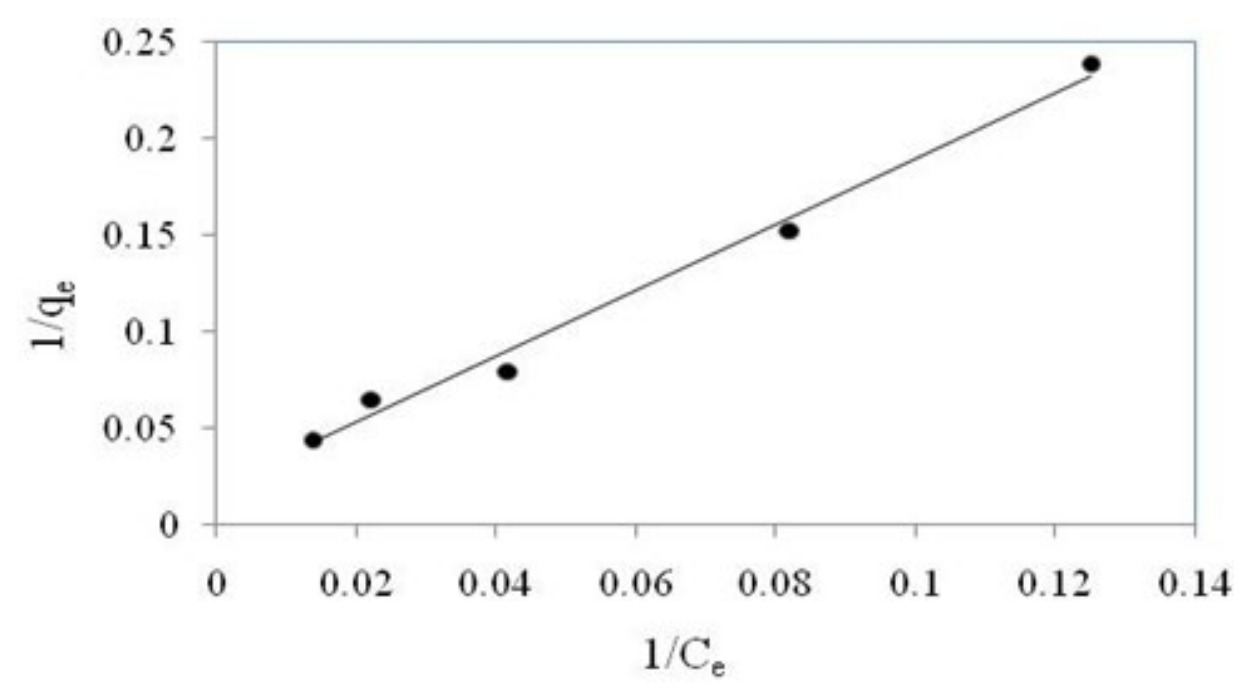

Figure 7. Langmuir plot for the adsorption of congo red dye by the adsorbent at optimum concentration 100 ppm, adsorbent dosage $1.0 \mathrm{~g} / \mathrm{L}, \mathrm{pH} 5$ and contact time $150 \mathrm{~min}$

Table 2. Maximum adsorption capacities of different types of bio-adsorbents

\begin{tabular}{lccl}
\hline Adsorbents & Adsorption capacity $\mathbf{( m g} / \mathbf{g})$ & Type of Dyes & References \\
\hline Water hyacinth & 53.76 & Congo red & Present study \\
\hline Water hyacinth & $17.58-46.35$ & Methylene blue & Murali and Uma, 2016 \\
\hline Water hyacinth root & 46.15 & Congo red & Kumar and Bilal, 2018 \\
\hline Water hyacinth root & 8.04 & Methylene blue & Soni et al., 2012 \\
\hline Rice Husk & 4.29 & Congo red & Taha et al., 2014 \\
\hline Sugarcane bagasse & 39.8 & Congo red & Zhang et al., 2011 \\
\hline Cashew nut shell & 5.18 & Congo red & Senthil et al., 2010 \\
\hline Kaolin & 5.44 & Congo red & Vimonses et al., 2009 \\
\hline Bagasse fly ash & 11.89 & Congo red & Mall et al., 2005 \\
\hline Neem leaf powder & 41.20 & Congo red & Bhattacharrya and Sharma, 2004
\end{tabular}

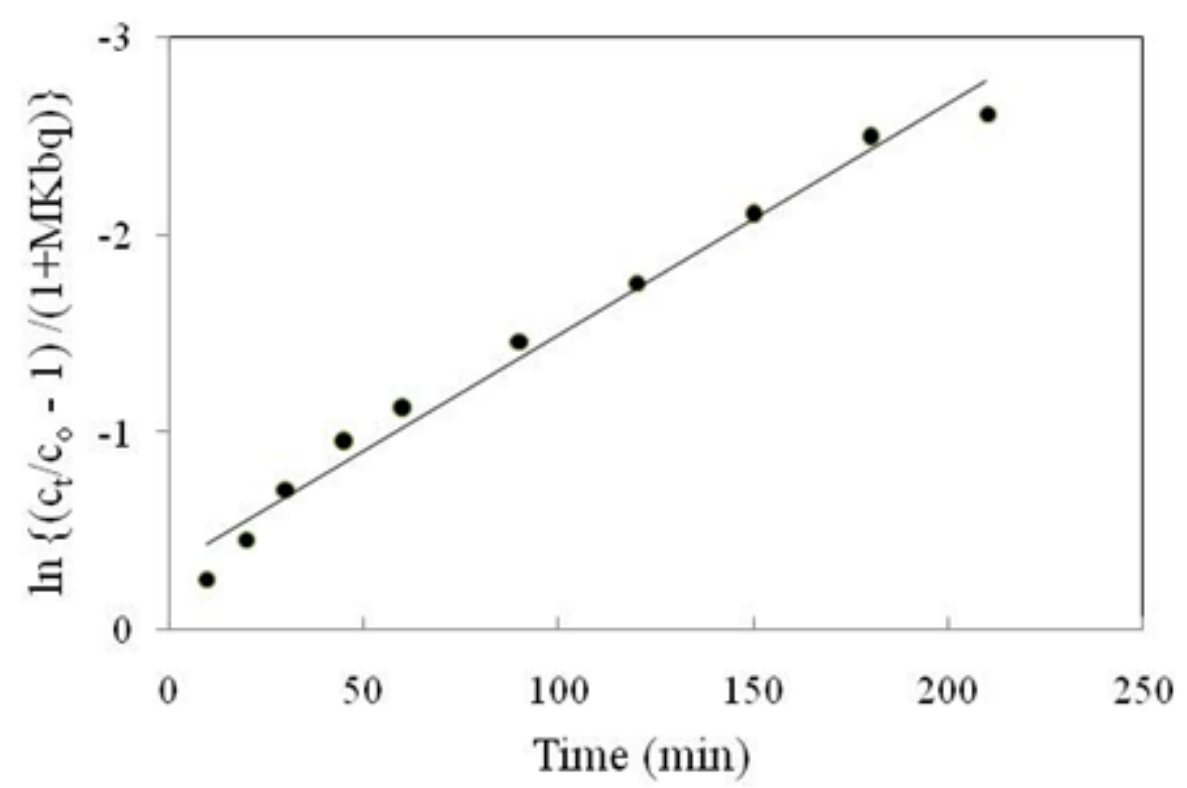

Figure 8. Mass transfer plot for the adsorption of Congo red by the adsorbent at optimum concentration 100 $\mathrm{ppm}$, adsorbent dosage $1.0 \mathrm{~g} / \mathrm{L}$ and $\mathrm{pH} 5$

The adsorption capacity $\left(Q_{0}\right)$ of the adsorbent was found to be $53.76 \mathrm{mg} / \mathrm{g}$. The adsorption capacity of the adsorbent under study is comparable to other bio-adsorbents reported in Table 2.

\section{Mass Transfer Analysis}

The plot of $\ln \left\{C_{t} / C_{0}-1 /\left(1+M K_{b q}\right)\right\}$ versus $t$ resulted a straight line shown in Figure 8 representing the applicability of the model. 
Table 3. Mass transfer analysis for adsorption of congo red on water hyacinth

\begin{tabular}{ccc}
\hline Adsorbents & Mass transfer constants, $\boldsymbol{\beta}_{s}(\mathbf{c m} / \mathbf{m i n})$ & Correlation coefficient, $\boldsymbol{R}^{\mathbf{2}}$ \\
\hline Water hyacinth & $62.39 \times 10^{-12}$ & 0.9825 \\
\hline
\end{tabular}

The value of mass transfer coefficient $(\beta)$ were determined graphically from the slope $\left\{\left(1+M K_{b q} / M K_{b q}\right) \beta S_{s}\right\}$ of the individual plots and presented in Table 3 .

The values obtained from the experimental analysis shown that the velocity of the adsorbate Congo red for transporting from bulk i.e. solution phase to solid phase was quite good (Bhattacharya et al., 2008).

\section{CONCLUSION}

In this study, Congo red dye was removed from aqueous solution quite successfully by water hyacinth as a natural adsorbent. The effect of various parameters like $\mathrm{pH}$, adsorbent dosage, initial dye concentration and contact time were evaluated on the uptake capacity of the adsorbent. The optimum dye removal by using water hyacinth as bio-adsorbent was achieved at $\mathrm{pH} 5$, concentration $100 \mathrm{ppm}$ and for contact time $150 \mathrm{~min}$. Monolayer adsorption capacity of the bio-sorbent was obtained to be $53.76 \mathrm{mg} / \mathrm{g}$, confirmed by Langmuir fitting. The results of the kinetic study suggests that adsorption of Congo red on the selected adsorbent followed pseudo second order kinetic model and the intra-particle diffusion model showed larger surface adsorption. The mass transfer analysis indicated advanced movement of adsorbate toward water hyacinth adsorbent.

\section{REFERENCES}

Awomeso, J. A., Taiwo, A. M., Gbadebo, A. M. and Adenowo, J. A. (2010). Studies on the pollution of water body by textile industry effluents in Lagos, Nigeria. J. Appl. Sci. Environ. San-it, 5, 353-359.

Alam, M. J., Das, B. C., Rahman, M. W., Biawas, B. K., Khan and M. M. R. (2014). Removal of dark blue-GL from wastewater using water hyacinth: a study of equilibrium adsorption isotherm. Desalination and Water Treatment, $1-6$.

Ajayi, T. O. and Ogunbayo, A. O. (2012). Achieving environmental sustainability in wastewater treatment by phytoremediation with water hyacinth (Eichhorniacrassipes). J. Sustain. Develop., 5(7), 80-90. https://doi.org/10.5539/jsd.v5n7p80

Ata, S., Imran, D. M., Rasool, A., Qasim, I. and UlMohsin, I. (2012). Equilibrium, thermodynam-ics, and kinetic sorption studies for the removal of coomassie brilliant blue on wheat bran as a low-cost adsorbent. J. Anal. Methods Chem., 405980.

Annadurai, G., Juang, R. S. and Lee, D. J. (2002). Use of cellulose based wastes for adsorption of dyes from aqueous solutions. J. Hazard. Mater., 92(3), 263-274. https://doi.org/10.1016/S0304-3894(02)00017-1

Aboul-Fetouh, M. S., Elmorsi, T. M., El-Kady, J. M. M. and El-Adawi, H. A. (2010). Water hya-cinth stems a potential natural adsorbent for the adsorption of acid green 20 dye. Environ. Sci., 5(4), 257-266.

Bhattacharya, K. G. and Sharma, A. (2004). Azadirachtaindica leaf powder as an effective bio-sorbent for dyes: a case study with aqueous Congo red solutions. $J$ Environ Manage, 71(3), 217-29. https://doi.org/10.1016/j.jenvman.2004.03.002

Bhattacharya, A. K., Naiya, T. K., Mandal, S. N. and Das, S. K. (2008). Adsorption, kinetics and equilibrium studies on removal of $\mathrm{Cr}$ (VI) from aqueous solutions using different low-cost adsorbents. Chemical Engineering Journal, 137, 529-541.

Choi, J. W., Song, H. K., Lee, W., Koo, K. K., Han, C. and Na, B. K. (2004). Reduction of COD and colour of acid and reactive dyestuff wastewater using ozone. Korean J. Chem. Eng., 21, 398. https://doi.org/10.1007/BF02705427

Cotoruelo, L. M., Marques, M. D., D1ªz, F. J., Rodr1'guez-Mirasol, J., Rodr1'guez, J. J. and Cordero, T. (2010). Equilibrium and kinetic study of Congo red adsorption onto lignin-based activated carbons. Trans. Porous Media, 83(3), 573-590. https:// doi.org/10.1007/s11242-009-9460-8

Cheng, Z., Zhang, L., Guo, X., Jiang, X. and Li, T. (2015). Adsorption behavior of direct red 80 and Congo red onto activated carbon/surfactant: process optimization, kinetics and equilibrium. Spectrochim Acta A Mol. Biomol. Spectrosc., 137, 1126-43. https:// doi.org/10.1016/j.saa.2014.08.138

Deans, J. R. and Dixon, B. G. (1992). Uptake of Pb2+ and Cu2+ by novel biopolymers. Water Res., 26(4), 469472. https:// doi.org/10.1016/0043-1354(92)90047-8

Fernandes, A. N., Almeida, C. A., Menezes, C. T., Debacher, N. A. and Sierra, M. M. (2006). Removal of methylene blue from aqueous solution by peat. J. Hazard. Mater., 144(1-2), 412-419. 
Garg, V. K., Amita, M. and Kumar, R. (2004). Basic dye (methylene blue) removal from simulat-ed waste water by adsorption using Indian rose-wood saw dust: a timber industry waste. Dyes Pigments, 63, 243-250. https://doi.org/10.1016/j.dyepig.2004.03.005

Ghorai, S. and Pant, K. (2005). Equilibrium, kinetics and break through studies for adsorption of fluoride on activated carbon. Sep. Puri. Technol, 42, 265-271. https:// doi.org/10.1016/j.seppur.2004.09.001

Gharbani, P., Tabatabaii, S. M. and Mehrizad, A. (2008). Removal of Congo red from textile wastewater by ozonation. Int. J. Environ. Sci. Tech., 5(4), 495-500. https://doi.org/10.1007/BF03326046

Hameed, B. H., Krishni, R. R. and Sata, S. A. (2009). A novel agricultural waste adsorbent for the removal of cationic dye from aqueous solutions. J. Hazard. Mater., 162(1), 305-311. https://doi.org/10.1016/j.jhazmat.2008.05.036

Ho, Y. S., Chiang, T. H. and Hsueh, Y. M. (2005). Removal of basic dye from aqueous solution using tree fern as a biosorbent process. Biochem, 40, 119-124.

Ho, Y. S. and Mckay, G. (1999). A kinetic study of dye sorption by bio sorbent waste product pith. Resour. Conserv. Recycling, 25, 171- 193. https://doi.org/10.1016/S0921-3449(98)00053-6

Janos, P., Buchtova, H. and Ryznarova, M. (2003). Sorption of dyes from aqueous solutions on-to fly ash. Water Res., 37(20), 4938-4944. https://doi.org/10.1016/j.watres.2003.08.011

Khan, M. A., Alemayehu, A., Duraisamy, R. and Berekete, A. K. (2015). Removal of lead ion from aqueous solution by bamboo activated carbon. International journal of water research, 5(2), 33-46.

Kumar, M. R. and Bilal, B. (2018). Removal of Congo Red from Dye Wastewater Using Ad-sorption. International Journal of Engineering and Techniques, 4(1).

Mokhtar, H., Morad, N. and Ahmad, F. F. F. (2011). Hyperaccumulation of copper by two spe-cies of aquatic plants. Intern. Conf. Environ. Sci. Eng. IPCBEE 8.IACSIT Press, Singapore.

Mahmood, Q., Zheng, P., Islam, E., Hayat, Y., Hassan, M. J., Jilani, G. and Jin, R. C. (2005). Lab scale studies on water hyacinth (EichhorniacrassipesMarts.Solms) for biotreatment of tex-tile wastewater. Caspian J. Environ. Sci., 3(2), 83-88.

Mall, I. D., Srivastava, V. C., Agarwal, N. K. and Mishra I. M. (2005). Removal of Congo red from aqueous solution by bagasse fly ash and activated carbon: kinetic study and equilibri-um isotherm analyses. Chemosphere, 61(4), 492-501. https://doi.org/10.1016/j.chemosphere.2005.03.065

McKay, G., Oterburn, M. S. and Sweeney, A. C. (1981). Surface mass transfer processes during col-our removal from effluent using silica. Water Res., 15, 327-331. https:/ / doi.org/10.1016/0043-1354(81)90036-1

Murali, K. and Uma, R. N. (2016). Removal of Basic Dye (Methylene Blue) Using Low Cost Biosorbent: Water Hyacinth. Int. J.Adv.Engg Tech/Vol. VII/Issue II/April-june/386-391.

Nigam, P., Armour, G., Banat, I. M., Singh, D. and Marchant, R. (2000). Physical removal of tex-tile dyes from effluents and solid-state fermentation of dye-adsorbed agricultural resi-dues. Bioresour. Technol., 72, 219-226. https://doi.org/10.1016/S0960-8524(99)00123-6

Nath, A., Sudip, C. and Chiranji, B. (2013). Bioadsorbtion of industrial dyes from aqueous solu-tion onto crassipes, equilibrium, kinetic, and sorption mechanism study. Desalin. Water Treat, 1-11, water hyacinth (Eichornia: 10.1080/19443994.2013.

Paul, E. and D. I. M. (2013). Adsorption of methyl red and methyl orange using different tree bark powder. Acad. Res. Int., 4(1), 34.

Pramanik, S. K., Abdullah-Al-Shoeb, M., IbnSina, A. A., Uddin, M. J., Datta, S. U. and M. A. (2011). Natural adsorbents for dye effluent of high strength COD and their microbiological analysis. Chem. J., 1(1), 29-35.

Robinson, T., McMullan, G., Marchant, R. and Nigam, P. (2001). Remediation of dyes in textile effluent: a critical review on current treatment technologies with a proposed alternative. Bioresour. Technol., 77(3), 247-255. https://doi.org/10.1016/S0960-8524(00)00080-8

Reddy, M. K., Mahammadunnisa, P., Ramaraju, S., Sreedhar, B. and Subrahmanyam, B. (2013). Low-cost adsorbents from bio-waste for the removal of dyes from aqueous solution. Environ. Sci. Pollut. Res. Int., 20(6), 4111-4124. https://doi.org/10.1007/s11356-012-1360-8

Senthil, K. P., Ramalingam, S., Senthamarai, C., Niranjanaa, M., Vijayalakshmi, P. and Sivanesan, S. (2010). Adsorption of dye from aqueous solution by cashew nut shell: studies on equilibrium isotherm, kinetics and thermodynamics of interactions. Desalination, 261(1-2), 52-60. https:// doi.org/10.1016/j.desal.2010.05.032

Soni, M., Sharma, A. K. and Srivastav, J. K. (2012). Adsorpitve Removal of Methylene Blue Dye from an Aqueous Solution using Water Hyacinth Root Powder as a low cost Adsorbent. Int. J. Chem. Sci. Appli, 3, 338-345.

Taha, D. N., Samaka, I. S., Mohammed, L. A. and Naize, A. S. (2014). Adsorption Studies of Direct Red 28 Dye Onto Activated Carbon Preparaed from Low Cost Material. Joumal of Civil and Environmental Research, 6(7). https://doi.org/10.4236/jep.2011.26093

Taha, M. E. (2011). Equilibrium Isotherms and Kinetic Studies of Removal of Methylene Blue Dye by Adsorptiononto Miswak Leaves as a Natural Adsorbent. Journal of Environmental Protection, 2, 817-827. 
Vijayaraghavan, K. and Yun, Y. S. (2008). Biosorption of C.I. Reactive Black 5 from aqueous so-lution using acidtreated biomass of Brown seaweed Laminaria sp. Dyes Pigments, 76, 726-732. https://doi.org/10.1016/j.dyepig.2007.01.013

Vadivalen, V. and Kumar, K. (2005). Equilibrium, kinetics, mechanism and process design for the sorption of methylene blue onto rice husk. Journal of Coloidall Interface Sceince, 28, 90-100. https://doi.org/10.1016/j.jcis.2005.01.007

Vimonses, V., Lei, S., Jin, B., Chow, C. and Saint, C. (2009). Kinetic study and equilibrium iso-therm analysis of Congo red adsorption by clay materials. ChemEng J, 148(2-3), 354-64. https://doi.org/10.1016/j.cej.2008.09.009

Vilaseca, M., Gutie, M. C., Grimau, V. L., Mesas, M. L. and Crespi, M. (2010). Biological treatment of a textile effluent after electrochemical oxidation of reactive dyes. Water Envi-ron. Res., 82, 176-181. https://doi.org/10.2175/106143009X447902

Zhang, Z., Moghaddam, L., O'Hara I. M. and Doherty W. O. S. (2011). Congo Red Adsorption by Ball-Milled Sugarcane Bagasse. ChemEngJ., 178, 122-8. 